\title{
Effects of Urban Farming Practices on Income Poverty Reduction in Dodoma Municipality, Tanzania
}

\author{
Adili Y Zella* \\ Department of Economic Studies, The Mwalimu Nyerere Memorial Academy (MNMA)-Zanzibar, Tanzania
}

Received: 阱 June 14, 2018; Published: 阱 June 26, 2018

*Corresponding author: Adili Y Zella, Department of Economic Studies, The Mwalimu Nyerere Memorial Academy (MNMA)-Zanzibar, Tanzania

\begin{abstract}
The main objective of this paper is to reveal the less known effects of urban farming practices on income poverty reduction in Dodoma Municipality, Tanzania. Collected primary and secondary data were analyzed both manually and by the use of SPSS software in which descriptive statistics and multiple responses presented by frequencies and cross tabulation employed. The findings show that the male raised higher income (61.7\%) compared to women (38.3\%) resulted from urban farming practices. It also shows that the majority of urban farmers use rain water compared to other sources of water. The capital availability found to be a problem (73.3\%); has income below TZS 90,000 per month. The study also revealed that urban farmers use poor technology in farming activities. However, the study found that urban farmers practice agro-forestry which help to prevent land degradation and to enrich soil fertility as well as acting as wind breakers and shade provision. It was found that, though urban farming practices contribute to reduce income poverty in the study area but there are some factors which found to hinder the improvement of urban farming such as inadequate water supply, inefficiency laws and by laws and lack of improved seeds due to insufficient capital. These problems can be minimized through early seed provision from government and NGOs, use of irrigation technology rather than depending on rainfall, efficiency and effectiveness implementation of laws and by-laws and increase area for urban farming as population increase in Dodoma municipality due to concentration of colleges/universities and government activities.
\end{abstract}

Keywords: Urban farming; Urban famers; Income poverty; Land degradation

\section{Introduction}

\section{Background information}

Urban farming is very extensive in urban areas in developing countries. Urban farming includes activities such as crop farming, vegetables, gardening, livestock keeping and poultry. It is estimated that; urban farming is practiced by about two thirds of urban workforce in developing countries [1]. Urban farming could contribute to mitigating the two most intractable problems facing third world cities which are poverty and waste management. Urban farming is one of several food security options for households. Similarly, it is one of several tools for making productive use of urban open spaces, treating urban waste, saving or generating income and employment and managing fresh water resources more effectively ibid, 2000.
The main motivation for urban farming is food production and/or higher income for personal consumption or sale ibid, 2000. Tanzania economy is still depending on agriculture as its main stay. In the year 2015, the contribution of the agriculture to the total GDP has been around 29\%, and contributed $70 \%$ to the total employment and 55\% of the country's foreign currency [2]. Dodoma urban as one of the semi-arid areas in the country, through municipal councils' authorities set strategies on encouraging farmers to put priority on production of drought resistant crops such as cassava, millet, sorghum and sunflowers in all areas with an annual rainfall between $400 \mathrm{~mm}-600 \mathrm{~mm}$ (Municipal Agricultural and Livestock Development Officer, 2016). In Miyuji ward there was more than 13.6 hectares which were used for growing grapes and other plants but now only 6.2 hectares are used for these activities 
(Dodoma Municipal Report, 2016). This shows that there is a decrease in urban farming practices in Miyuji ward more than half of the area which planned for agriculture.

\section{Statement of the problem and significance of the study}

Dodoma municipal council has 196,000 hectares suitable for cultivation but only 137,200(70\%) hectares have been cultivated. Out of cultivated area, 11433(12\%) hectares are used for urban farming and only $1509(1.1 \%)$ hectares are used by small farmers in Dodoma municipal council. Urban farming in Dodoma was mostly practiced by farmers in Miyuji, Msalato, Veyula, Mzakwe, Makutupora and other areas in Urban and Peri-Urban (Dodoma Municipal report, 2016). About $68 \%$ of the estimated 16,579 human population (2016) in Miyuji ward are relying on arable farming and livestock keeping.

The ward estimated to have 3832 hectares of arable land but only 1734.7 hectares are used for farming (Miyuji WEO office report, 2016).Despite of the hectares used for urban farming in Miyuji ward is being decreasing, yet the living standard of people, especially urban farmers, is very poor in the ward. Therefore, this study intended to examine the effects of urban farming practices on income poverty reduction in Dodoma municipality. The findings of the study will be useful in reducing income poverty to urban farmers by promoting urban farming through identified constraints and opportunities facing urban farming practices and formulating competent national policies which will be used in improving urban agriculture, and help to add literature related to urban farming.

\section{Research objectives}

General objective: The main objective of this research was to examine the effects of urban farming practices on income poverty reduction in Dodoma municipality.

Specific Objectives: Specifically, the study was intended to:

Examine factors affecting the performance of urban farming practices in the study area

Examine contribution of urban farming on income poverty reduction in the study area.

Examine the effects of urban farming on the environment in the study area.

\section{Conceptual framework}

The primary interested variable of this study is the dependent variables which is assessment of urban farming practices. The intermediate variables will be used in attempt to explain the dependent variables; these variables are amount of inputs, farmers' income, Extension services and farming practice. Independent variables acting on and operating through intermediate variables which cause or determine or influence dependent variable to occur. The Figure 1 below shows the conceptual framework in a clear and simple way.

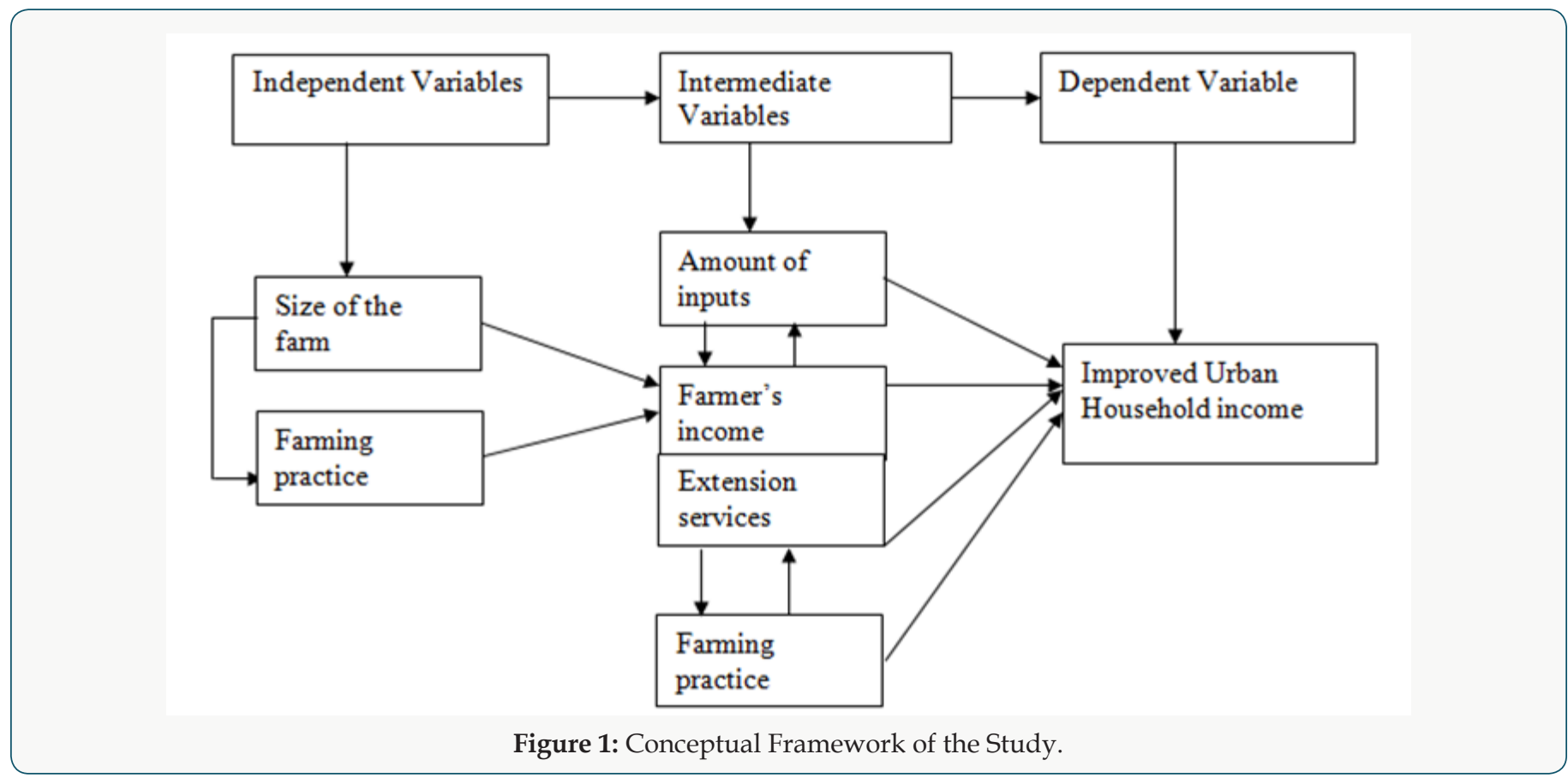

\section{Research Methodology}

\section{The study area}

The researcher chooses Miyuji ward as the study area in Dodoma municipality due to the fact that, it is among the area which urban farming practices were given priority and there were planned land for such activities (Dodoma Municipal council report, 2016). Miyuji ward is located in urban area of Dodoma Municipality which lies

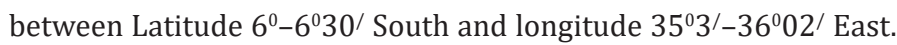
Dodoma Municipality has an area of $421 \mathrm{~km}^{2}$ of which $346 \mathrm{~km}^{2}$ is 
arable land, $57.1 \mathrm{~km}^{2}$ is residential and industrial area $17.9 \mathrm{~km}^{2}$ occupied by natural resources and planted forests, mountains and non-arable land (Figure 2). According to projection basing on year 2012 population census, the current population of Dodoma municipality accounts to 446,579 inhabitants, where by 240,481 inhabitants live in urban areas and 206, 098 live in peripheral zone consisting of villages. The population size of Miyuji ward in 1988 was about 14,288; 2002 was about 15,779; and 2012 was about14, 965. This situation shows that the size of Miyuji was dramatically decline for about $-0.47 \%$ /year from 2002 to 2012 .

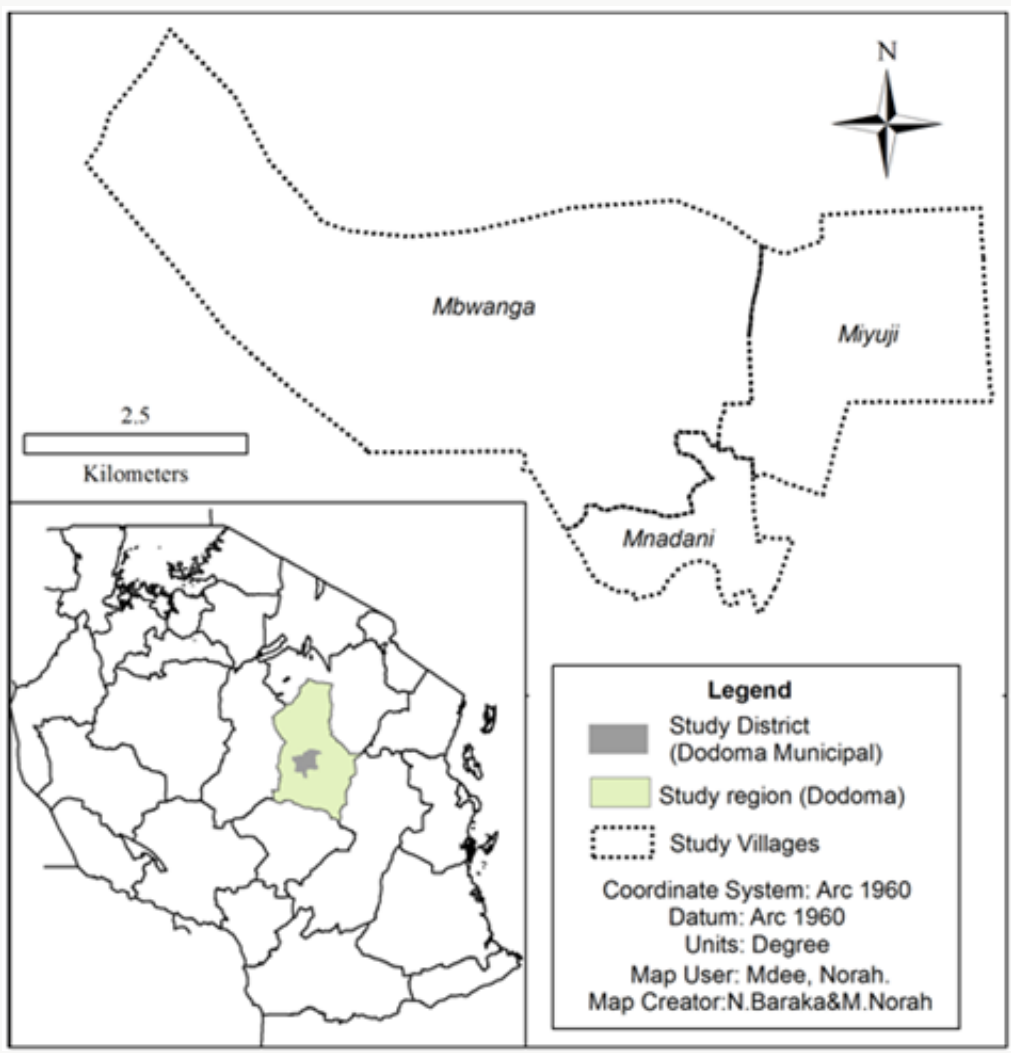

Figure 2: Map of the study area.

\section{Data types and sources}

Both primary and secondary data were used. Primary data such as income levels and farm sizes were collected in Miyuji ward by using household questionnaire. Secondary data such as number of extension workers, number of market centers were collected from street and ward executive offices by reading different reports and documents existent.

\section{Sampling design}

Sampling frame: A list of all households was used to pick respondents where a sample of 70 respondents was taken to represent the total population. Judgmental sampling was categorizing samples into different groups such as household with large arable land, household with small arable land, local leaders, extension workers (EW) and District Agricultural Officer (DAO)

Sampling unit: The sampling unit for this study was a household.

Sample size: The sampling size for this study was 100 (Table 1), which involves 90 households and key informants. Yamane
(1967), provides a simplified formula for calculating sample size as follows:

$$
n=\frac{N}{1+N(e)^{2}}
$$

Where: $\mathrm{n}=$ Sample size

$\mathrm{N}=$ Population size (Number of households in my case)

e=Level of Precision

In Miyuji ward: $\mathrm{N}=3684$

$\mathrm{e}=10 \%$ as recommended to social sciences

$$
n=\frac{3684}{1+3684(0.1)^{2}}
$$

$\mathrm{n}=97 \sim 100$ households

Sampling procedure: Both probability and no-probability sampling techniques was used.

Probability sampling: The method was used to obtain the sample required by employing stratification where the population was divided into a number of homogenous sub-population and a sample helped the researcher to obtain 90 respondents. 
Table 1: Respondent Sample Composition.

\begin{tabular}{|c|c|c|c|c|c|}
\hline \multirow{2}{*}{ Category of respondent } & \multirow{2}{*}{ District } & \multicolumn{3}{|c|}{ Mitaa } & \multirow{2}{*}{ Total } \\
\hline & & Mbwanga & Miyuji & Mnadani & \\
\hline Urban farmers & & 30 & 30 & 30 & 90 \\
\hline Mtaa Executive Officer(MEOs) & & 1 & 1 & 1 & 3 \\
\hline Mtaa C/P & & 1 & 1 & 1 & 3 \\
\hline Extension Officer & 1 & & 1 & & 2 \\
\hline Ward Counselor & & & 1 & & 1 \\
\hline Ward Executive Officer (WEO) & & & 1 & & 1 \\
\hline Total & 1 & 32 & 35 & 32 & 100 \\
\hline
\end{tabular}

Non-probability sampling: The method was used to obtain the sample required by employing purposive sampling technique to select the 10 sample required to meet the objectives includes selection of AO (Agriculture Officers), MEOs (Mitaa Executive Officers), and WEO (Ward Executive Officer).

\section{Data collection methods}

Both primary and secondary data collection methods were used.

Primary data: Primary data was collected by using the following methods:

Interview: Structured questionnaire was used to enable face to face meeting in which the interviewer asked the interviewee questions and recorded responses. This method was used to obtain information from different respondents.

Observations: The method was used by visiting the selected areas to observe different things related to study such as how urban farming is practiced.

Focused group discussion: Focused group discussion enabled respondents to express and exchange their views on how they practice urban farming. This group involved Mtaa C/p, Extension officer, and few urban farmers. Group of not more than 25 people is recommended since they will be difficult to manage [3]. Fourteen respondents were invited to participate in focus group discussion for Miyuji ward as follow; Ward executive officer (1), Mtaa government chairpersons (3), Mtaa executive officer (3), Ward agriculture extension officer (1), and prominent urban farmers (6). Group discussions were conducted in a ward executive office where flip charts and marker pens were available after seeking permission from ward authorities. Questions were written on the flip chart, and the chairman who was elected by the participants guided the discussions by first reading the questions loudly for every member to hear and allowed for contributions through raising a hand. The group leader's role also was to make sure that one person does not dominate and influence the discussion. The researcher took notes as well as probing questions when judged that the respondent's statement was ambiguous. The information collected was used to supplement the household questionnaire.
Secondary data: Secondary data was gathered through.

Documentary review: The method was involving reading various published and unpublished materials related with the study. These materials include internet, books, Magazine, newspaper and Journals.

\section{Data Processing, analysis and presentation}

Data processing: Data was processed both manually and by computer using SPSS (Statistical package for social sciences) and MS-Excel where the exercise involved editing questionnaires, coding, clearing and verifying the entered data for easy interpretation.

Data Analysis: The data was analyzed manually and by the use of SPSS Version 11.5 software. Bivariate analysis technique was used in which the researcher examined the relationship between two variables for example farm size and Household income by the use of Cross- tabulation method.

Data presentation: The results from the research are presented by using charts, tables and graphs.

\section{Limitations of the study}

Time was not enough to cover the whole ward instead only 3 streets (mitaa) were represented.

Some respondent especially key informants were reluctant to give out the needed information as they thought that, they will be responsible when the wrong things/issues concerned with urban farming been recognized by the institution, however observation and literature review overcome this difficult.

Disturbances/bureaucracy of getting permission to conduct research in a study area.

\section{Results and Discussion}

\section{General characteristics of the respondents}

The study population comprised of males and females with different ages, family size and education background (Table 2). Of the household heads interviewed, $53.3 \%$ of the respondents were between 35-44 years old and 46.7\% were between 25-34 years old. This was important because these age groups are the one who 
practice urban farming; understand the historical trend of their areas as well various indigenous technical knowledge. The study mitaa were found to have large household sizes. Results show that 55.6\%have 6-10 persons per household and $44.4 \%$ have $1-5$ persons. This is due to the behavior and culture of excluding family plan, of which results into a lot of dependents to feed and take care of Education background of the surveyed population is mainly primary education (90.0\%), very few had college education (6.7\%), and $3.3 \%$ had secondary education. Despite of having primary and secondary schools but the number joining secondary schools is small due to financial base of study population.

Table 2: General information on residents of study villages.

\begin{tabular}{|c|c|c|c|c|}
\hline \multirow{2}{*}{$\begin{array}{l}\text { Information } \\
\text { (a)Age class: }\end{array}$} & \multicolumn{4}{|c|}{ Mitaa } \\
\hline & Miyuji n=30 & Mbwanga $n=30$ & Mnadani n=30 & Total $\mathrm{N}=90$ \\
\hline 25-34 years & $13(45.0 \%)$ & $15(50.0 \%)$ & $13(45.0 \%)$ & $41(46.7 \%)$ \\
\hline $35-44$ years & $17(55.0 \%)$ & $15(50.0 \%)$ & $17(55.0 \%)$ & $49(53.3 \%)$ \\
\hline \multicolumn{5}{|l|}{ (b)Sex: } \\
\hline Male & $21(70.0 \%)$ & $17(55.0 \%)$ & $18(60.0 \%)$ & $56(61.7 \%)$ \\
\hline Female & $9(30.0 \%)$ & $13(45.0 \%)$ & $12(40.0 \%)$ & $34(38.3 \%)$ \\
\hline \multicolumn{5}{|c|}{ (c)Education level: } \\
\hline Primary & $28(93.3 \%)$ & $27(90.0 \%)$ & $26(86.70 \%)$ & $81(90.0 \%)$ \\
\hline Secondary & $0(0.0 \%)$ & $0(0.0 \%)$ & $3(10.0 \%)$ & $3(3.3 \%)$ \\
\hline College & $2(6.7 \%)$ & $3(10.0)$ & $1(3.3 \%)$ & $6(6.7 \%)$ \\
\hline \multicolumn{5}{|c|}{ (d)Household size: } \\
\hline 1-5Persons & $12(40.0 \%)$ & $17(55.0 \%)$ & $11(36.7 \%)$ & $40(44.4 \%)$ \\
\hline 6-10Persons & $18(60.0 \%)$ & $13(45.0 \%)$ & $19(63.3 \%)$ & $50(55.6 \%)$ \\
\hline
\end{tabular}

According to URT [4]; World Bank (2014); and Deloitte [5], one of the signs of both income and non-income poverty in the country is the low level of literacy and numeracy. The literacy level in Tanzania is now estimated to be $68 \%$, down from $90 \%$ achieved in the 1980s. The gross enrolment rate for primary school pupils was $77.8 \%$ in 1996, down from $90 \%$ in 1980s. the literacy rate for youths and adults in the year 2014 was $76 \%$ and $73 \%$ for male and female youths respectively; and $75 \%$ and $61 \%$ for male and female adults respectively World Bank (2014).The Tanzanian government has managed to pay teachers' salaries and allowances but number of teachers employed is not enough despite the efforts made to recruit more teachers due to agenda of having at least one secondary school in each ward and primary school in each village. With free tuition fees in public schools, the number of girls will be increased in schools as parents had have tendencies to choose between boys and girls to educate before the year 2016 because of cost sharing [6-8].

\section{Factors affecting the performance of urban farming practices}

Water availability: Availability of water is an important factor for urban farming practices. Miyuji ward is within semiarid region of Dodoma where enough rainfall for urban farming practices is a problem. The study mitaa in miyuji ward based on multiple responses (Table 3) found to have water mostly from rainfall (46.2\%), 23.5\% shallow wells, 19.3\% underground water, $7.6 \%$ pipe water and $3.4 \%$ borehole. The results show that many urban farmers in Miyuji ward prefer rain harvesting as source of water, and due to low water table in Dodoma region, underground water also seems to be preferred although it require some fund for investment in it like pump machine, fuel etc.

Table 3: Main source of Water in Miyuji Ward.

\begin{tabular}{|l|c|c|}
\hline \multicolumn{1}{|c|}{ Source of water } & Frequency & Percentages \\
\hline (a)Pipe water & 9 & 7.6 \\
\hline (b)Borehole & 4 & 3.4 \\
\hline (c)Shallow wells & 28 & 23.5 \\
\hline (d)Rainfall & 55 & 46.2 \\
\hline (e)Underground water & 23 & 19.3 \\
\hline Total & 119 & 100 \\
\hline
\end{tabular}

Laws and by laws: The study mitaa found to have by laws that deal with urban farming. The results Table 4 shows that $77.7 \%$ of respondents in study mitaa understand and respect by laws present while only $22.3 \%$ claims that they do not know if there is by laws for making urban farming sustainable. By laws is very important for guiding urban farming practices. The following by laws which enforced in the study area based on multiple responses Table 5 shows that $45.3 \%$ of urban farmers responded to bylaw dealing with protection of soil erosion by restrict quarry activities, 36\% protection of forests (cutting down of trees), 10.7\% protection of water and $8 \%$ protection of illegal farm burning. The study made revealed that $80.4 \%$ of the urban farmers in the study area are 
aware with existing by-laws and its effectiveness. However, 19.6\% of urban farmers complained that the existing by-laws are not enforced hence are not effective. It was established that $90.2 \%$ of

urban farmers want any person acting against the existing by-laws to be penalized the rest $9.8 \%$ want any criminal to be jailed (Table $6)$.

Table 4: Presence of by Laws Dealing with Urban Farming.

\begin{tabular}{|c|c|c|c|c|c|}
\hline Presence of by-laws & Miyuji & Mbwanga & Mnadani & Frequency & Percentage \\
\hline Yes & 21 & 26 & 23 & 70 & 20 \\
\hline No & 9 & 4 & 7 & 90 & 22.3 \\
\hline Total & 30 & 30 & 30 & 100 \\
\hline
\end{tabular}

Table 5: By laws guiding urban farming.

\begin{tabular}{|l|c|c|}
\hline \multicolumn{1}{|c|}{ By laws } & Frequency & Percentages \\
\hline (a)Protection of soil erosion by restricts quarry activities. & 54 & 45.3 \\
\hline (b)Protection of illegal farm burning & 11 & 8 \\
\hline (e) Protection of forests & 37 & 36 \\
\hline (f)Protection of water sources & 14 & 10.7 \\
\hline Total & 116 & 100 \\
\hline
\end{tabular}

Table 6: Efficiency and Effectiveness of By-laws Guiding Urban Farming.

\begin{tabular}{|c|c|}
\hline Information & Percentages \\
\hline (a)Efficiency and effectiveness: & 80.4 \\
\hline Yes & 19.6 \\
\hline No & 100 \\
\hline Total & 90.2 \\
\hline (b)Efficiency and effectiveness of available by-laws: & 9.8 \\
\hline Any person acting against the existing by-laws to be penalized & 100 \\
\hline Jail those people fail or reject to pay fine. & \\
\hline Total & \\
\hline
\end{tabular}

Table 7: Income level of Respondent per Month.

\begin{tabular}{|c|c|c|c|c|}
\hline Income per month & Employed & Unemployed & Total & Percentage \\
\hline Below TZS 60,000 & 15 & 20 & 35 & 19 \\
\hline TZS 60,000-89,000 & - & 19 & 11 & 21.1 \\
\hline TZS 90,000-119,000 & 6 & 5 & 17 & 12.2 \\
\hline TZS 120,000-149,000 & - & 6 & 8 & 18.9 \\
\hline Above TZS 149,000 & 2 & 67 & 90 & 8.9 \\
\hline Total & 23 & & & 100 \\
\hline
\end{tabular}

Capital Availability: Urban farming needs starting and operating capital so as to harvest considerable crops per acre and end products results from livestock and poultry. Capital helps to buy chemicals, fertilizers and other inputs helps in farming practices (Personal Observation). The study mitaa found to have different income groups in which $61.1 \%$ of study population has income per month above TZS 60,000 (Table 7). The results show that $38.9 \%$ of the urban farmers are living in absolute income poverty for both employed and unemployed and cannot even have power to buy any input for farming or self-sustenance. That majority with high income above TZS 60,000 can use the money earned to buy different equipment. During focus group discussion it was found that, urban farmers are not recognized in financial institutions for providing them loans unless they form a group of five persons or above and follow long procedures until given that loan. Also these urban farming practices are also done by employed people so as to raise household income, reduce income poverty and provide food to households' members who are large in number. Also the study 
found that, urban farmers in Miyuji ward are practiced by both men and women from all income groups where by the majority of them were from below TZS 60,000 income earners as shown in Table 8 . It was established that those urban farmers grow food crops for security and income generation as stipulated by Nugent $[9,10]$ and

Table 8: Income level of Respondent per Month interms of Sex.
URT [7]. In Miyuji ward women who engaged in urban agriculture are actively participate in urban garden for home production but also in food processing and marketing though in Miyuji ward women are involved in small scale production as explained much by Mouget [10] and URT [7].

\begin{tabular}{|c|c|c|c|c|}
\hline Income per month & Male & Female & Total & Percentage \\
\hline Below TZS 60,000 & 24 & 10 & 34 & 20 \\
\hline TZS 60,000-89,000 & 14 & 6 & 12 & 13.3 \\
\hline TZS 90,000-119,000 & 6 & 6 & 16 & 17.8 \\
\hline TZS 120,000-149,000 & 11 & 5 & 8 & 8.8 \\
\hline Above TZS 149,000 & 1 & 34 & 90 & 100 \\
\hline Total & 56 & 74 & \\
\hline
\end{tabular}

Market availability: The study area found to have markets for their products from urban farming practices. The results show that $87.7 \%$ of study households said they have market for their farming products. This shows that in Miyuji ward market for urban farming products is not a serious problem what is required is to increase crops production. Crops produced includes millet, cassava, sorghum, sunflower, grapes, groundnuts, njugu, maize, vegetables, tomatoes and others; while livestock keeping includes cows, goats and pigs; and poultry which mostly includes hens (Table 9). Due to increase of higher learning institutions in Dodoma urban, it is likely the market to be extended and scarcity of this products resulted from urban farming practices increase and leads to poverty reduction to those people involved in these practices.

Table 9: Market availability of Crops, Livestock and Poultry.

\begin{tabular}{|c|c|c|c|c|c|}
\hline Market availability & Miyuji & Mbwanga & Mnadani & Frequency & Percentage \\
\hline Yes & 27 & 25 & 27 & 79 & 87.7 \\
\hline No & 3 & 5 & 3 & 90 & 12.3 \\
\hline Total & 30 & 30 & 30 & 90 \\
\hline
\end{tabular}

Plot size and type of tools used for agriculture: The study area found to have scarcity of land for urban farming. The results show that $84.4 \%$ of study households own land and only $15.6 \%$ rent those lands for urban farming plots (Table 10). Also $100 \%$ of the study area own 1-4 acres of land and within this study population $95.6 \%$ claims that land is not enough and $85.6 \%$ propose average farmland required to be $5-9$ acres and $14.4 \%$ propose to remain Table 10: Land Ownership, Availability and Required.
1-4 hectares with maximum land size of 4 acres. Due to the use of hand hoe (low technology) in study area for agricultural activities, farmland shortage will continue to be a problem until the situation is reversed. Most urban farmers claim that, though urban agriculture is potentially viable and productive but not a panacea to solve the most severe problems of food security in Miyuji ward as explained also much by Nugent [9] and Mboganie [11].

\begin{tabular}{|c|c|c|c|c|}
\hline \multirow{2}{*}{$\begin{array}{c}\text { Information } \\
\text { (a)Land ownership: }\end{array}$} & \multicolumn{4}{|c|}{ Mitaa } \\
\hline & Miyuji $n=30$ & Mbwanga $\mathrm{n}=30$ & Mnadani $\mathrm{n}=30$ & Total $\mathrm{N}=90$ \\
\hline Individual & $27(90.0 \%)$ & $24(80.0 \%)$ & $25(83.3 \%)$ & $76(84.4 \%)$ \\
\hline Rent & $3(10.0 \%)$ & $6(20.0 \%)$ & $5(16.7 \%)$ & $14(15.6 \%)$ \\
\hline \multicolumn{5}{|c|}{ (b)Land owned in hectares: } \\
\hline 1-4 acre & $30(100.0 \%)$ & $30(100.0 \%)$ & $30(100.0 \%)$ & $90(100.0 \%)$ \\
\hline \multicolumn{5}{|l|}{ (c)Land available: } \\
\hline Enough & $2(6.7 \%)$ & $1(3.3 \%)$ & $1(3.3 \%)$ & $4(4.4 \%)$ \\
\hline Not enough & $28(93.3 \%)$ & $29(96.7 \%)$ & $29(96.7 \%)$ & $86(95.6 \%)$ \\
\hline \multicolumn{5}{|l|}{$\begin{array}{l}\text { (d)Average farmland } \\
\text { required: }\end{array}$} \\
\hline 1-4 acre & $6(15.8 \%)$ & $2(10.5 \%)$ & $5(16.7 \%)$ & $13(14.4 \%)$ \\
\hline 5-9 acre & $24(84.2 \%)$ & $28(89.5 \%)$ & $25(83.3 \%)$ & $77(85.6 \%)$ \\
\hline
\end{tabular}


Use of fertilizers: The made in the study area found to have high fertilizers users. The results show that $63.3 \%$ use fertilizers and $36.7 \%$ are not using fertilizers (Table 11). This shows that disparities of income groups are the determinant for using fertilizers as those urban farmers with high income group are the one with ability to buy fertilizers. Also those practice either livestock keeping and agricultural or poultry keeping and agriculture can use manure type of fertilizer which is not costly [12]. Kinds of fertilizers used are shown in Table 12. The increase in fertilizer prices and reduction in credit have hit urban farmers harder because they are on poorer land which needs more of fertilizer which they are less able to afford. This has resulted in increasing cultivation of marginal areas with associated deforestation and erosion problems.
Table 11: Fertilizers Usage in Farming.

\begin{tabular}{|c|c|c|}
\hline Fertilizers usage & Frequency & Percentage \\
\hline Yes & 57 & 63.3 \\
\hline No & 33 & 36.7 \\
\hline Total & 90 & 100 \\
\hline
\end{tabular}

Table 12: Kind of Fertilizers Used.

\begin{tabular}{|c|c|c|}
\hline Kind of fertilizers & Frequency & Percentages \\
\hline UREA & 21 & 36.8 \\
\hline Manure & 36 & 63.2 \\
\hline Total & 57 & 100 \\
\hline
\end{tabular}

\section{Contribution of urban farming on income poverty reduction}

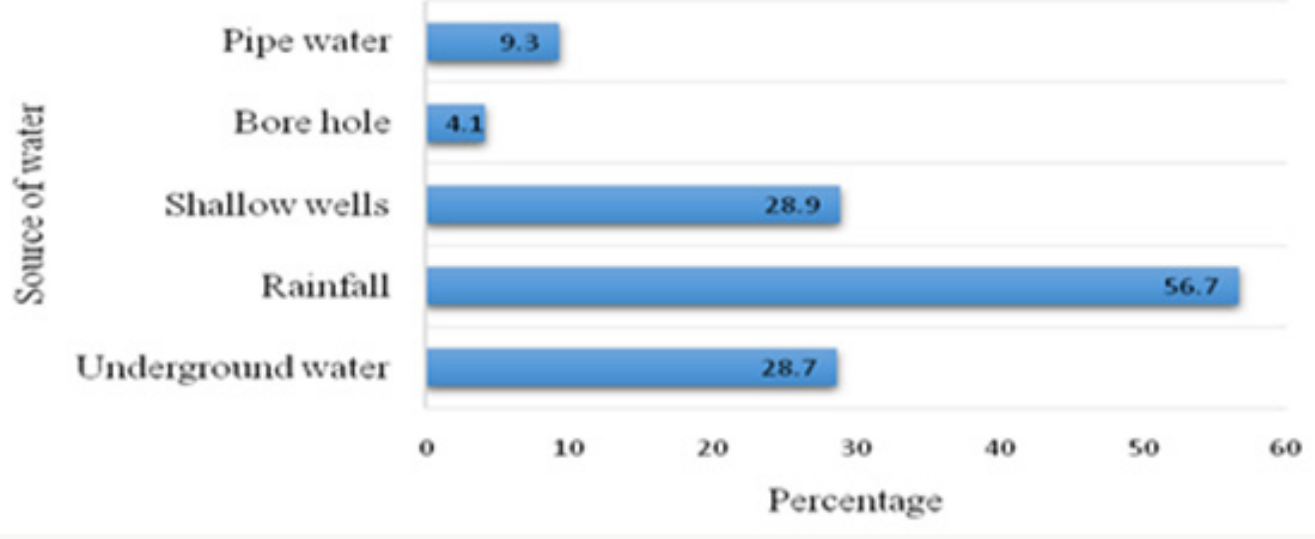

Figure 3: Source of Water in Miyuji Ward.

Activities of urban farming: The study made found to have high number of household using rain fed farming as their main source of water for urban farming [13]. Results shows that, $56.7 \%$ use rain harvesting only $9.3 \%$ and $4.1 \%$ use pipe water and borehole respectively (Figure 3). This shows that those use pipe water from DUWASA are the one who cultivate leafy vegetables includes chinese, beans, sweet potatoes leaves, cassava leaves and non-leafy vegetable includes tomato, cucumber and carrot; and cultivate both vegetable and fruits includes orange, grapes and pawpaw. The common crops grown by both groups of different main water sources includes millet (23.6\%), sunflower (23.2\%), sorghum $(21.4 \%)$, maize $(14.5 \%)$, groundnuts $(7.7 \%)$, cassava $(5 \%)$, and njugu (4.5\%)(Table 13). Also livestock kept includes cows (28.1\%), goats (6.3\%) and poultry (hens) (65.6\%) (Table 14). These crops grown and livestock kept are both for subsistence use in families and business to increase income of household whereby keeping hens found to be done by large number of households in study area. The study found that, men in Miyuji ward dominate commercial urban food production such as sunflower and groundnuts and selling of livestock kept. Most of women earn/control the money from milk and eggs selling. The study also revealed that children were involved in urban farming activities through weeding and watering. Involving children is contrary to child labour rights [14].
Table 13: Crops grown kept in Miyuji Ward.

\begin{tabular}{|c|c|c|}
\hline Information & Frequency & Percentages \\
\hline Crops grown: & & \\
\hline Millet & 21 & 23.6 \\
\hline Cassava & 5 & 5 \\
\hline Sorghum & 19 & 21.4 \\
\hline Sunflower & 21 & 23.2 \\
\hline Groundnuts & 7 & 7.7 \\
\hline Njugu & 5 & 4.5 \\
\hline Maize & 12 & 14.5 \\
\hline Total & 90 & 100 \\
\hline
\end{tabular}

Table 14: Livestock kept in Miyuji Ward.

\begin{tabular}{|c|c|c|}
\hline Information & Frequency & Percentages \\
\hline Animal kept: & & \\
\hline Cows & 25 & 28.1 \\
\hline Goats & 6 & 6.3 \\
\hline Hens & 59 & 65.6 \\
\hline Total & 90 & 100 \\
\hline
\end{tabular}


Table 15: Crops production per acre.

\begin{tabular}{|c|c|c|c|c|}
\hline Information & Below 2bags & 2-4bags & 4-6bags & 6-8bags \\
\hline (a)Crops production: & & & & $0.00 \%$ \\
\hline Millet & $12.40 \%$ & $15.50 \%$ & $0.00 \%$ & $0.00 \%$ \\
\hline Cassava & $0.00 \%$ & $11.30 \%$ & $5.20 \%$ & $4.10 \%$ \\
\hline Sorghum & $21.60 \%$ & $17.50 \%$ & $9.30 \%$ & $0.00 \%$ \\
\hline Sunflower & $8.20 \%$ & $35.10 \%$ & $0.00 \%$ & $0.00 \%$ \\
\hline Groundnuts & $12.40 \%$ & $5.20 \%$ & $0.00 \%$ & $0.00 \%$ \\
\hline Njugu & $15.50 \%$ & $0.00 \%$ & $4.10 \%$ & $13.40 \%$ \\
\hline Maize & $0.00 \%$ & $7.20 \%$ & & \\
\hline
\end{tabular}

Amount produced and sold and price of products: The study population found to have medium production of urban farming products [15]. Crops production per acre as shown in Table 15 below shows that, $35.1 \%$ produce $2-4$ bags per acre of sunflower, $21.6 \%$ below 2 bags of sorghum, $25.8 \%$ produce $4-6$ bags of millet per acre, $13.4 \%$ produce 6-8 bags per acre of Maize, Njugu 15.5\% produce below 2 bags per acre, $11.3 \%$ produce 2 -4bags of cassava per acre, and $12.4 \%$ produce Groundnuts below 2 bags per acre. Animal production based on end products shows (Figure 4) that, $43.3 \%$ produce hens' eggs and $18.6 \%$ produce milk During focus group discussion, it was shown that, urban farmers of Miyuji ward use products obtained for home use and business whereby most of them sell all products in order to get income for covering some expenses for example paying fees for their children, health issues, water bills and all other household necessities needed rather than priotised using crops produced to solve the problem of food insecurity. Market availability for products produced is not a problem in a study area [16]. Results in Figure 4 shows that $88 \%$ of the respondents in study area have market for their products and only $12 \%$ have no market. This shows that as population increase in Dodoma urban then demands for urban farming products increases, therefore production should be increased in order sustain the available population.

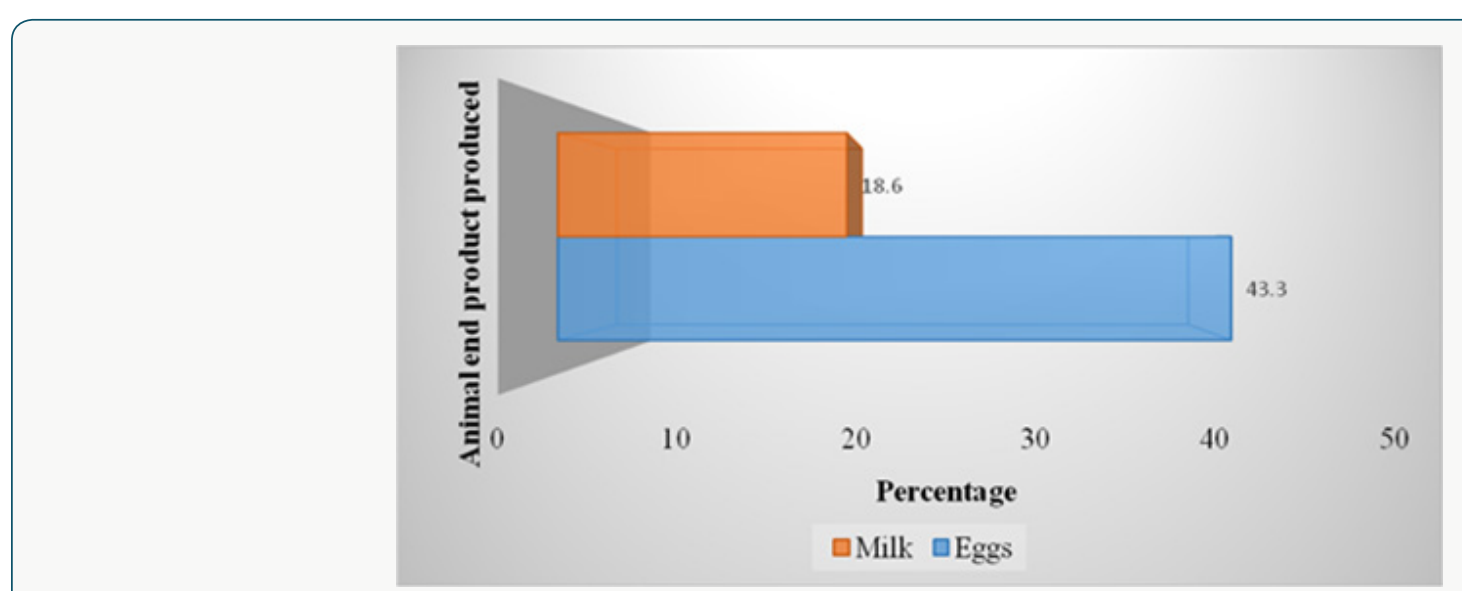

Figure 4: Animal end product produced.

When the researcher interviewed households, it was found that, price of crops products varies depending on demand especially during parliamentary meetings and higher learning students' institutions studying semester's periods. Animal products includes milk and eggs found to have constant price of TZS 1000 per liter and TZS 500 per egg while the price of cow and chicken are subject to change ranging from TZS 300.000 to 600,000 depending on size and specie of cow, while chicken range from TZS7000 to 15,000. In order this farming practices to be improved so as to increase production, the study households suggested as shown in Table
16. $30.1 \%$ said if they can be supplied by early seeds provision, adopt irrigation technology (28\%), establishment of market nearby, increase number of extension officers (8.3\%), separating agriculture and livestock area (6.2\%), education and training provision to urban farmers on good method of agriculture $(3.2 \%)$ and Subsides provided on fertilizers and pesticides to reach urban farmers (3.2\%) tgether with financial support from Banks and Credit agencies [17], altogether can improve urban farming practices and more urban dwellers can engage themselves as explained much by Nelson, 1996. 
Table 16: Suggestion given by urban farmers on the improvement of their farming practices.

\begin{tabular}{|c|c|c|}
\hline Information & Frequency & Percentages \\
\hline (a)Early seeds provision from government & 27 & 19 \\
\hline (b)Establishment of market nearby & 24 & 21 \\
\hline (c)Use of irrigation technology & 6 & 28 \\
\hline (d)Separating for agriculture and grazing area & 8 & 3.1 \\
\hline (e)Increase number of extension officers & 3 & 3.3 \\
\hline (f)Subsides provided by government on fertilizers and pesticides should reach urban farmers & 3 & 3.2 \\
\hline (g)Education and training provision to urban farmers on good method of farming & 90 \\
\hline Total & 100 \\
\hline
\end{tabular}

\section{Effects of urban farming on the environment}

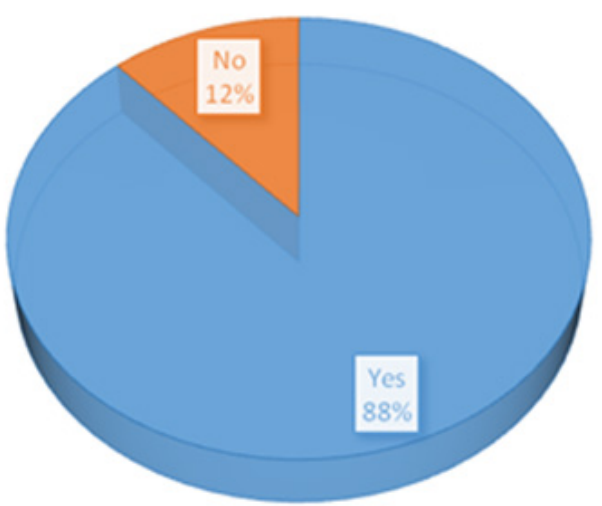

Figure 5: Market availability for crops and animals products.

Chemicals used and cow dung disposal: The study found that urban farmers have low usage of chemicals in farming practices. Results shows that, $71.7 \%$ do not use any insecticides or pesticides in crops production and only $28.3 \%$ use insecticides and pesticides for the crops production (Figure 5). This shows that farming products produced in Miyuji ward have little concentration of chemicals which can have negative effect to human being. However, during interview with ward agricultural officer, it was shown that sometimes aerial sprays to kill "koleakolea" have been done in the area few years ago. Also during focus group discussion, it was revealed that cow dung disposal in farm plots make them to increase nutrients as a results production per acre increase compared to plots without any fertilizer. Additionally, it was found that cow dung can be used for production of bio-gas which is alternative source of energy rather than concentrating using fuel wood and charcoal as the main source of energy in study area.

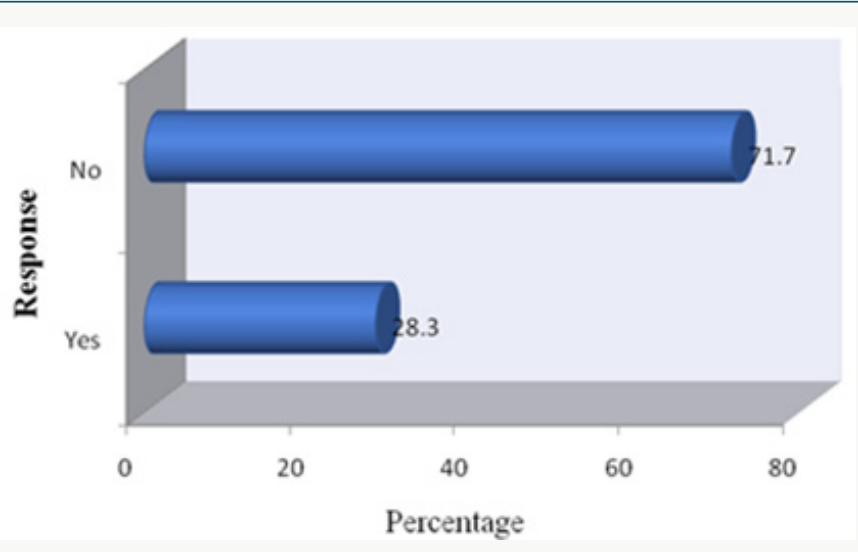

Figure 6: Insecticides/Pesticides usage in farms. 


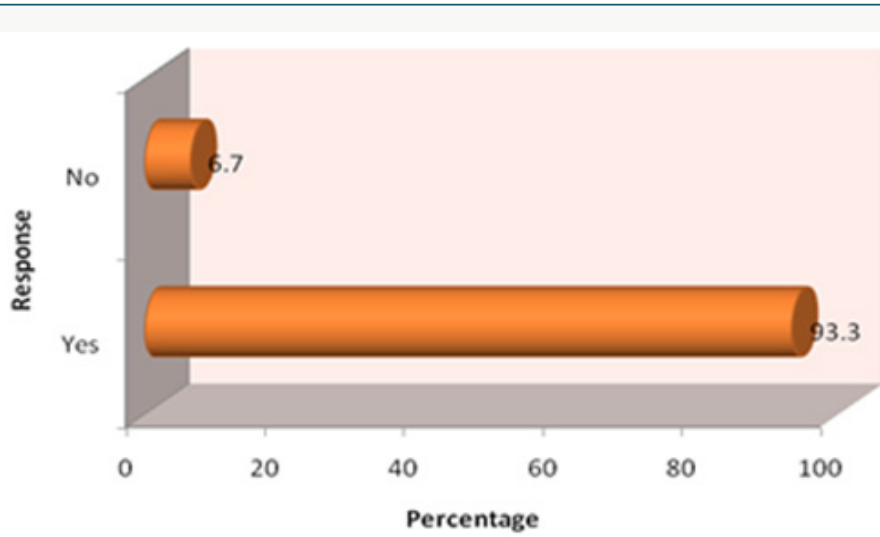

Figure 7: Land Degradation Resulted From Urban Farming Practices.

The study area found to have land degradation resulted from urban farming practices. Results shows that $93.3 \%$ of study households experienced land degradation resulted from urban farming practices and only $6.7 \%$ do not experience it. This shows that poor farming practices present in the area, so the duty of extension officers to reverse the situation will be appreciated (Figure 6). Land degradation is among of the effects on urban farming which experienced in the study area [18]. Types of land degradation experienced are shown in Table 17. Also it shows that

Table 17: Types of Land Degradation experienced in study area.

\begin{tabular}{|c|c|c|}
\hline Information & Frequency & Percentages \\
\hline (a)Soil erosion & 19 & 22.3 \\
\hline (b)Soil infertility & 19 & 12.7 \\
\hline (c)Deforestation & 12 & 15.5 \\
\hline (d)Loss of vegetation cover & 14 & 1.6 \\
\hline (e)Loss of habitat for wildlife & 2 & 12.7 \\
\hline (f)Low crop yield & 12 & 12.7 \\
\hline (g)Loss of fodder & 12 & 100 \\
\hline Total & 90 & \\
\hline
\end{tabular}

Table 18: Major Reasons for Increasing and Decreasing Land degradation.

\begin{tabular}{|c|c|c|}
\hline Information & Frequency & Percentages \\
\hline (a)Major reasons for increasing land degradation: & 56 & $37.20 \%$ \\
\hline Deforestation & 34 & 16.7 \\
\hline Sand fetching & & 22.2 \\
\hline (b) Major reasons for decreasing land degradation: & 15 & 61.1 \\
\hline Destocking & 20 & 25 \\
\hline Reduction of burning activities & 55 & 2 \\
\hline The use of composite manure & & \\
\hline
\end{tabular}




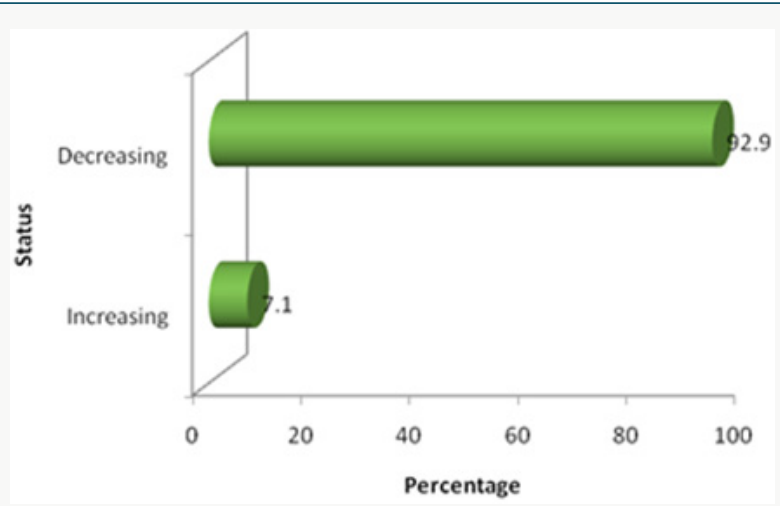

Figure 8: Status of Land Degradation.

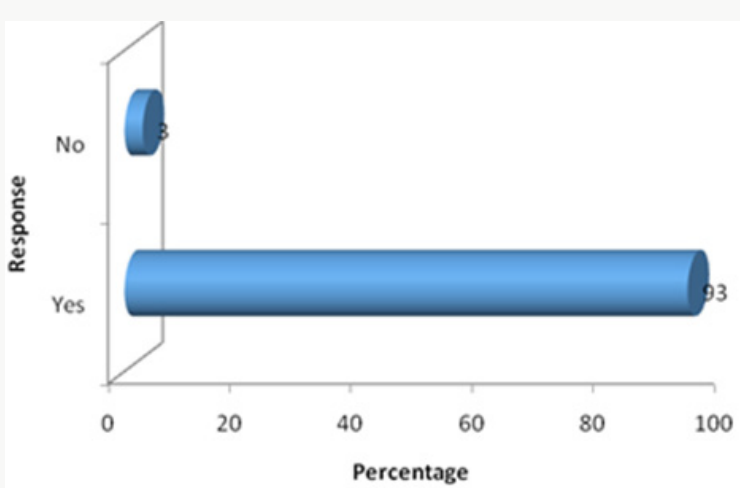

Figure 9: Tree planting.

Table 19: Purpose of growing trees in study area.

\begin{tabular}{|l|c|c|}
\hline \multicolumn{1}{|c|}{ Information } & Frequency & Percentages \\
\hline (a)Fuel wood & 14 & 15.6 \\
\hline (b)Building materials & 14 & 15.6 \\
\hline (c)Soil fertility maintenance & 24 & 26.7 \\
\hline (d)Wind breakers & 13 & 14.8 \\
\hline (e)Shades & 25 & 27.4 \\
\hline Total & 90 & 100 \\
\hline
\end{tabular}

Planting trees: Planting trees is a positive strategy towards environmental in many areas of the world, and collaborative measures whereby, all community together practice this tree planting for the benefit of extracting carbon dioxide gas concentration resulted from daily productive activities Smit and Nasr, 1997. The study found that $93 \%$ of respondents in study

Table 20: Number of Trees Planted Per Year. area planted trees and only $7 \%$ did not plant trees (Figures 8 \& 9). This shows that indigenous technical knowledge and NGOs play a good role in providing conservation education and importance of growing trees for the benefit of urban farming practices. The study population found to have behavior of planting trees for shades rather than combating fuel wood shortage. Results shows that $27.4 \%$ of planted trees are meant for shades, $26.7 \%$ for soil fertility maintenance, $15.6 \%$ for fuel wood and building materials respectively, and $14.8 \%$ for wind breakers (Table 19). Also the study revealed that in Miyuji ward have high populations who plant few trees per year. Results in Table 20 shows that $40 \%$ of respondents planted two trees per year and $60 \%$ plant more than two trees per year. This implies that, as times goes on and those trees planted being protected then in few years to come Miyuji ward can have large amount of tree.

\begin{tabular}{|c|c|c|c|c|c|}
\hline Number of trees planted & Miyuji & Mbwanga & Mnadani & Frequency & 36 \\
\hline Two & 12 & 13 & 11 & 27 & 30 \\
\hline Three & 9 & 9 & 9 & 12 & 13.3 \\
\hline Four & 3 & 3 & 6 & 9 & 15 \\
\hline More than five & 6 & 5 & 30 & 90 & 100 \\
\hline Total & 30 & 30 & 4 & & \\
\hline
\end{tabular}




\section{Conclusion and Recommendations}

\section{Conclusion}

Generally, urban farming practices contribute much to reduce income poverty in Dodoma Municipal especially in Miyuji ward. Based on analyzed data most of respondents are in a position of improving their living standard and getting their basic human needs due to involvement in urban farming practices though there are some factors which observed to hinder urban farming practices in the study area such as inadequate water, inefficiency laws and by laws which govern urban farming practices, lack of enough capital, small plot size, low technology and lack of nearby market to sell their crops and livestock products.

\section{Recommendations}

Urban farming practices is a new employment opportunity to urban dwellers as the study shows it increase income to households, fight food insecurity, provide room for environmental conservation through planting trees and adopting proper way of farming and other benefits associated with urban farming. In order this sector to be improved and increase production, the following issues found in the study area must be taken into account:

Early seed provision from the government and non-government organization can help to improve urban farming practices in Miyuji ward. This can be facilitated by ward agricultural extension officer.

Improvements of irrigation method can help to improve urban farming practices rather than depends much on tap and rain harvest water. Urban farmers, extension officers and government are in position to incorporate in order to reach consensus.

Regular education to the urban farmers from urban farmers' expertise can help to increase the crop and livestock yield hence poverty reduction to the urban farmers.

The village government must ensure implementation of existing laws and by laws governing urban farming practices which help to conserve the environment so as to be conducive for practicing urban farming.

Town planners should plan an alternative area for urban farming practices to suit the urban farmers as their areas are too small as compared to the size of their family.

\section{References}

1. Bakker NM, Dubbeling S, Guendel U, Sabel Koschella, H Dezeeuw (2000) Growing cities, growing food-urban agriculture on the policy Agenda. Germany.

2. BOT (Bank of Tanzania) (2015) Annual Report. Dar es Salaam, Tanzania

3. Mikkelsen B (2005) Methods for Development Work and Research: A Guide for Practitioners. Sage Publications, London, UK, pp. 296.

4. United Republic of Tanzania (URT) (1998) The National Poverty Eradication Strategy. Vice President Office, Government Printer, Dar es salaam, Tanzania, pp. 12.

5. Deloitte (2016) Tanzania Economic Outlook: The Story Behind the Numbers. p. 14

6. Maliyamkono M (1997) Tanzania on the Move. TEMA Publishers Company Ltd, Dare es salaam, Tanzania, pp. 177.

7. URT (United Republic of Tanzania) (2016) Pre-Primary, Primary and Secondary Education Statistics in Brief. President Office - Regional Administration and Local Government, Government Printer, Dar es salaam, Tanzania, pp. 147.

8. Fox L (2016) Supporting Economic Transformation: Gender, Economic Transformation and Women's Economic Empowerment in Tanzania. DFID, London

9. Nugent R (1997) The significance of urban Agriculture. Published by City Farmer. Canada's Office of Urban Agriculture.

10. Mougeot LJA (1999) URBAN Agriculture Definition presence, potential and risks, policy challenges. CFP Report series 31, IDRC, Ottawa, Canada.

11. Foeken D, A Mboganie Mwangi (2000) Increasing food security through urban farming in Nairobi in growing cities, growing food-urban Agriculture on the policy Agenda (ed. N Bakker, M Dubbelling, S Guendel, U Sabel Koshella, HDE Zeeuw, DSE, Eurasburg, Germany.

12. Binns T, K Lynch (1988) Feeding Africa's Growing cities into the 21st century, the potential of urban Agriculture. Journal of International Development 10(6): 777-793.

13. Nelson T (1996) Closing the Nutrient Loop. World watch 9(6): 3.

14. Nugent RA (2000) The impact of urban agriculture on the household and local economies in Growing cities, growing food (Ed. N Bakkes, M Dubbeling, S Gundel, U Sabel - Koschella, H de Zeeww). DSA. Eurasburg pp. 76-79.

15. Sassen S (1996) Metropelen des Weltmarts - Die newe Rolle der global cities campus. Frankfurt, Germany.

16. Straiffeller F (2000) Rural and urban agriculture by valorization of domestic waste in demostic in DESAP in Africa Euro summer school DESAR - Decentralized Sanitation and Re-use.

17. United Republic of Tanzania (URT) (2000) National Human Settlements Development Policy. Government printer, Dar es Salaam, Tanzania.

18. United Republic of Tanzania (URT) (2002) Livestock National Policy: Improvement in Livestock Production, Ministry of Agriculture and Livestock, Dar es Salaam, Tanzania. 


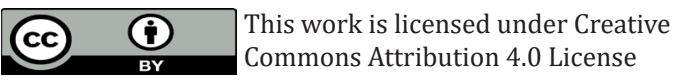

To Submit Your Article Click Here: Submit Article

DOI: $10.32474 /$ CIACR.2018.03.000161

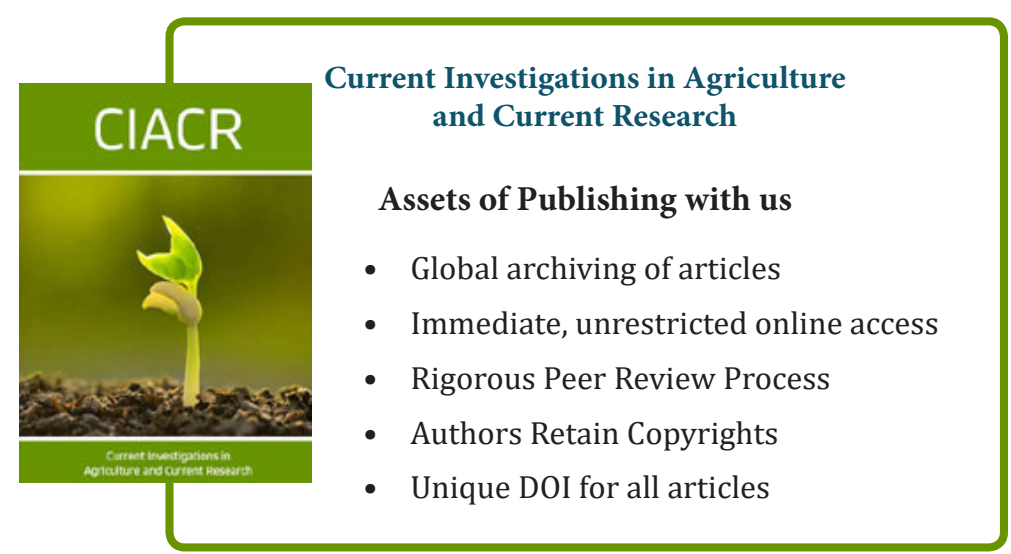

